(C) 2016

\author{
Молчанова А. В., аспірант
}

(науковий керівник - доктор економічних наук М. С. Самойлік)

Полтавська державна аграрна академія

\title{
ЕКОЛОГІЧНІ АСПЕКТИ ВПЛИВУ ПОЛІГОНІВ ТВЕРДИХ ПОБУТОВИХ ВІДХОДІВ НА АГРОЛАНДШАФТ, ВОДНЕ СЕРЕДОВИЩЕ ТА АТМОСФЕРНЕ ПОВІТРЯ
}

\section{Рецензент - доктор сільськогосподарських наук, професор П. В. Писаренко}

В умовах структурної перебудови економіки України, впровадження нових способів, методів та форм господарювання призводить до зростання кількості сучасних промислових та продовольчих товарів для населення $i$, відповідно, до зростання утворення твердих побутових відходів. У процесі розвитку ичивілізаиії людство неминуче перетворює свою планету на величезний смітник, а природа не має механізмів утилізації $і$ знищення відходів, вироблених суспільством, тому останні накопичуються в біосфері у геометричній прогресіі. На даний час проблема поводження з відходами знаходиться поруч з охороною навколишнього середовища від забруднення хімічними та біологічними компонентами, щзо постійно присутні в них, а також із захистом здоров'я населення, яке перебуває в зоні їхнього безпосереднього чи непрямого впливу. Проблема поводження з відходами є однією з ключових екологічних проблем, $і$ усе більш вагомою $в$ ресурсному аспекті. Полігони твердих побутових відходів - типовий приклад антропогенної діяльності. Для них характерні низка ознак хімічного забруднення грунтів, поверхневих, грунтових та підземних вод, рослинних груп, атмосферного повітря, які $\epsilon$ об'єктами різноманітних екологічних досліджень.

Ключові слова: ТПВ (тверді побутові відходи), вилив, трунт, вода, атмосферне повітря, полігон.

Постановка проблеми. Сучасне поводження 3 відходами нераціональне, має за результат їх зростаюче накопичення і несумісне 3 державною концепцією сталого розвитку України. В Україні нараховується щонайменше 12538 звалищ, 3 яких 6690 несанкціоновані та 5317 невпорядковані. Це близько 160 тис. га, це один 3 найвищих показників нагромаджень відходів у світі. Так, у 2005 р. на території України було виявлено і закрито 2423 несанкціонованих звалищ загальною площею 222,5 гектарів [4]. Темп збільшення обсягів утворення ТПВ в Україні перевищують світові тенденції в 2-3 рази і становлять $10 \%$ і більше [8]. Проте чітке уявлення щодо засобів їх обстеження та благоустрою території відсутнє. Проблема складування і зберігання відходів у даний час $€$ однією з найактуальніших і життєво важливих для України екологічних і економічних проблем.
Аналіз останніх досліджень і публікацій, у яких започатковано розв'язання проблеми. Зроблено оцінку екологічного стану земельних ділянок, зайнятих відходами та об'єктами поводження 3 ними, Орловою Тетяною Олександрівною. Так, із ТПВ можна добувати корисні властивості. Г. Г. Гелетухою та 3. А. Марценюком проаналізовано технології видобутку і використання біогазу на полігонах ТПВ. С. В. Онищенко і М. С. Самойлік у своїй роботі «Екологоекономічна оцінка забруднення навколишнього середовища в системі екологічно безпечного розвитку регіонів України» детально дослідили проблеми забруднення НПС у системі сталого розвитку регіонів України, а також важливих еколого-економічних проблем сьогодення - поводження $з$ ТПВ та використання біоенергетичного потенціалу регіонів України. Великого забруднення від ТПВ зазнає атмосферне повітря на полігонах і території навколо полігонів. Ці дослідження висвітлені у працях «Методика расчета количественных характеристик выбросов загрязняющих веществ в атмосферу от полигонов твердых бытовых и промышленных отходов» Н. Ф. Абрамовим, Э. С. Санниковим, К. Б. Русаковим та «Екологічна безпека атмосферного повітря територій навколо полігонів твердих побутових відходів» Н. В. Научу, А. О. Водяник. Загальні теоретично-методичні питання щодо екологічних аспектів вирішення народногосподарських проблем та ефективності природоохоронних заходів, пов'язаних 3 вирішенням проблем поводження з відходами, розроблялися в роботах О. Ф. Балацкого, І. К. Бистрякова, П. П. Борщевського, Э. Буна, С. І. Дорогунцова, А. Б. Качинського, В. О. Лимаренка, В. С. Міщенка, Л. Г. Мельника, Л. Хенса, В. Я. Шевчука та інших. Значний вклад у розробку питань визначення екологічних пріоритетів природоохоронної діяльності під час поводження з відходами, зокрема з ТПВ, а також у науково-методичне та нормативно-правове забезпечення відповідної діяльності внесли своїми працями М. П. Вашкулат, Д. Вілсон, Б. О. Горлицький, А. А. Дрейер, Б. Г. Манелис, В. С. Мі- 


\section{СТОРІНКА МОЛОДОГО ВЧЕНОГО}

щенко, С. І. Маторін, К. С. Никольський, І. Я. Сігал, $Ф$. В. Столберг та інші, проте багато аспектів поводження 3 відходами, зокрема 3 ТПВ, залишаються недостатньо вирішеними.

Метою даної роботи є дослідження впливу полігонів твердих побутових відходів на навколишнє середовище та розробка шляхів щодо покращання екологічного стану довкілля у зоні їх впливу.

Для досягнення поставленої мети передбачалося вирішити наступні завдання:

- вивчити і обгрунтувати вплив ТПВ на екологічні складові грунту, води, повітря;

- дати оцінку впливу на навколишнє середовище (грунт, водне середовище та атмосферне повітря) полігонів ТПВ загалом в Україні та Полтавської області;

- надати рекомендації проведення заходів щодо мінімізації забруднення навколишнього середовища навколо полігонів ТПВ.

Методи досліджень: польовий, методи математичної статистики, економічна оцінка.

Предмет досліджень - процеси, що відбуваються в навколишньому середовищі (грунті, воді та атмосферному повітрі) під впливом полігону твердих побутових відходів.

Практична значимість. Проведене дослідження $\epsilon$ комплексним аналізом впливу функціонуючого полігону ТПВ на навколишне середовище і може бути використана для розробки моделювання та прогнозування впливу такого об'єкту на довкілля.

Результати досліджень. У роботі досліджено вплив полігонів твердих побутових відходів на грунт, водне середовище та атмосферне повітря, детально проаналізовано вплив полтавського міського полігону ТПВ на питну воду (станом на 2015 рік).

Проведені дослідження питної води поблизу полтавського полігону ТПВ показують, що забарвленість води перевищує допустимі показники і наявність заліза у воді в 2,5 рази перевищує допустиму норму.

Полігони твердих побутових відходів відповідно до ЗУ «Про відходи» є спеціальними спорудами, призначеними для ізоляції та знешкодження ТПВ, та повинні гарантувати санітарноепідеміологічну безпеку населення. На полігонах повинна забезпечуватися статична стійкість ТПВ 3 урахуванням динаміки ущільнення, мінералізації, газовиділення, максимального навантаження на одиницю площі, можливості раціонального використання ділянки після закриття полігону. Однак переважна більшість полігонів ТПВ в
Україні не відповідають санітарним нормам. Внаслідок цього виникла велика кількість екологічних проблем, а саме: забруднення підземних вод фільтратом із цих звалищ шляхом інфільтрації забруднених вод у підземні водоносні горизонти та міграції забруднюючих компонентів разом 3 підземним потоком. Найбільш уразливими компонентами навколишнього середовища при цьому $є$ грунтові та поверхневі води, породи зони аерації, також забруднюється атмосферне повітря. Запобігання ризику забруднення навколишнього середовища від полігонів та звалищ ТПВ залежить від знань про закономірності міграції хімічних елементів та органічних сполук.

Забруднення від полігонів твердих побутових відходів поширюється у грунт стічними, інфільтраційними та підземними водами, незважаючи на встановлені очисні споруди. Коли забруднення надходять у великій кількості, вміст розчинного кисню знижується до рівня, якого недостатньо для життя живих організмів. До різкого зниження інтенсивності біохімічних процесів призводять важкі метали ( $\mathrm{Pb}, \mathrm{Cu}, \mathrm{Zn}, \mathrm{Cd}, \mathrm{Hg})$, що містяться в побутових відходах. Вони характеризуються також мутагенною і токсичною дією щодо живих організмів у грунті [6].

Грунтовий покрив $\epsilon$ одним із депонуючих середовищ. Його екологічний стан великою мірою залежить від різних факторів. Основними джерелами його забруднення в межах впливу полігону є: фільтратні стоки, кислі гудрони, присутні в атмосфері забруднюючі речовини надходять у грунти, а наявні в ньому рухомі форми токсичних речовин частково поглинаються рослинами, частково $з$ дощовими і талими водами проникають у підземні водоносні горизонти.

Визначення якості питної води по вул. Озерна в с. Макухівка, у найближчому населеному пункті до полтавського полігону ТПВ [2].

Забарвленість питної води поблизу полтавського полігону ТПВ перевищує гранично допустимі показники відповідно до ГОСТУ 3351-74. Через годину відібрані зразки 3 прозорого кольору набули темно-сірого.

Проведені дослідження показують, що наявність заліза у воді в 2,5 рази перевищують допустиму норму, відповідно до ГОСТУ 4011-72.

Незадовільний стан геологічного і суміжних 3 ним середовищ у зоні впливу полігонів і неорганізованих звалищ пов'язаний 3 тим, що місця видалення відходів не відповідають санітарногігієнічним нормам і експлуатуються без застосування превентивних і надійних заходів ізоляції їх від підземних вод. 
СТОРІНКА МОЛОДОГО ВЧЕНОГО

\section{1. Якість питної води (органолептичні показники)}

\begin{tabular}{|c|c|c|c|c|}
\hline $\begin{array}{c}\text { № } \\
\text { п/п }\end{array}$ & НД на метод випробувань & Назва показника & Допустимі рівні & Фактичне значення \\
\hline 1 & Забарвленість & ГОСТ 3351-74 & Не більше 35 градусів & 40 градусів \\
\hline 2 & $\begin{array}{c}\text { Запах при } 20{ }^{\circ} \mathrm{C} \text { i } \\
\text { при нагріванні до 60 }\end{array}{ }^{\circ} \mathrm{C}$ & ГОСТ 3351-74 & Не більше 3/3 балів & $3 / 3$ балів \\
\hline 3 & $\begin{array}{c}\text { Каламутність за } \\
\text { стандартною шкалою }\end{array}$ & ГОСТ 3351-74 & Не більше 2,03 мг/дм ${ }^{3}$ & 1,7 мг/дм ${ }^{3}$ \\
\hline 4 & Смак і присмак при $20^{\circ} \mathrm{C}$ & ГОСТ 3351-74 & Не більше 3 балів & 3 бали \\
\hline
\end{tabular}

\section{2. Якість питної води (фізико-хімічні показники)}

\begin{tabular}{|c|c|c|c|c|c|c|}
\hline $\begin{array}{l}\text { № } \\
\Pi / \Pi\end{array}$ & $\begin{array}{c}\text { Назва } \\
\text { показника }\end{array}$ & $\begin{array}{l}\text { Одиниці } \\
\text { виміру }\end{array}$ & $\begin{array}{l}\text { НД на метод } \\
\text { випробувань }\end{array}$ & Допустимі рівні & $\begin{array}{l}\text { Фактичне } \\
\text { значення }\end{array}$ & Похибка \\
\hline 1 & Залізо & мг/дм ${ }^{3}$ & ГОСТ 4011-72 & Не більше 1,0 & 2,5 & $+/-25 \%$ \\
\hline 2 & $\begin{array}{c}\text { Загальна } \\
\text { жорсткість }\end{array}$ & ммоль/дм & ГОСТ 4151-72 & Не більше 10,0 & 2,6 & $+/-15 \%$ \\
\hline 3 & Сухий залишок & мг/дм ${ }^{3}$ & ГОСТ 18164-72 & $\begin{array}{c}\text { Не більше } \\
1500,0\end{array}$ & 160,0 & $+/-12 \%$ \\
\hline 4 & Нітрати & мг/дм ${ }^{3}$ & ГОСТ 18826-73 & Не більше 50,0 & Менше 0,1 & $+/-30 \%$ \\
\hline 5 & Алюміній & мг/дм ${ }^{3}$ & ГОСТ 18165-89 & $\begin{array}{l}\text { Фактичне } \\
\text { значення }\end{array}$ & Менше 0,02 & $+/-30 \%$ \\
\hline 6 & \begin{tabular}{|c|} 
Водневий \\
показник (рН)
\end{tabular} & од. $\mathrm{pH}$ & ДСТУ 4077-2001 & $6,5-8,5$ & 7,1 & $\begin{array}{c}+/-0,1 \text { од. } \\
\text { pH }\end{array}$ \\
\hline 7 & Кальцій & мг/дм ${ }^{3}$ & $\begin{array}{l}\text { ДСТУ ISO } \\
6058: 2003\end{array}$ & $\begin{array}{l}\text { Фактичне } \\
\text { значення }\end{array}$ & 38,1 & $+/-15 \%$ \\
\hline 8 & Марганець & $\mathrm{Mг} /$ дм $^{3}$ & ГОСТ 4974-72 & Не більше 0,5 & 0,14 & $+/-25 \%$ \\
\hline 9 & Хлориди & мГ/дм ${ }^{3}$ & ГОСТ 4245-72 & Не більше 350,0 & 12,4 & $+/-30 \%$ \\
\hline 10 & $\begin{array}{c}\text { Поліфосфати } \\
\text { залишкові }\end{array}$ & мг/дм ${ }^{3}$ & ГОСТ 18309-72 & $\begin{array}{l}\text { Фактичне } \\
\text { значення }\end{array}$ & 0,05 & $+/-30 \%$ \\
\hline 11 & Гідрокарбонати & мг/дм ${ }^{3}$ & ГОСТ 23268.3-78 & $\begin{array}{l}\text { Фактичне } \\
\text { значення }\end{array}$ & 109,8 & $+/-15 \%$ \\
\hline 12 & $\begin{array}{c}\text { Перманганатна } \\
\text { окислюваність }\end{array}$ & мг/дм ${ }^{3}$ & ГОСТ 26449.2-85 & Не більше 5,0 & 1,8 & $+/-30 \%$ \\
\hline 13 & Нітрити & мг/дм ${ }^{3}$ & ГОСТ 4192-82 & Не більше 3,3 & Менше 0,003 & $+/-50 \%$ \\
\hline 14 & Азот амонійний & мГ/дм ${ }^{3}$ & ГОСТ 4192-82 & Не більше 2,6 & 0,57 & $+/-25 \%$ \\
\hline 15 & Фториди & $\mathrm{Mг} /$ дм $^{3}$ & ГОСТ 4386-89 & Не більше 1,5 & 0,18 & $+/-18 \%$ \\
\hline 16 & $\begin{array}{l}\text { Загальна } \\
\text { лужність }\end{array}$ & ммоль/дм ${ }^{3}$ & $\begin{array}{c}\text { ДСТУ ISO } \\
9963-1: 2007\end{array}$ & $\begin{array}{l}\text { Фактичне } \\
\text { значення }\end{array}$ & 1,4 & $+/-15 \%$ \\
\hline 17 & Магній & мг/дм ${ }^{3}$ & $\begin{array}{l}\text { ДСТУ ISO } \\
6059-2003\end{array}$ & $\begin{array}{l}\text { Фактичне } \\
\text { значення }\end{array}$ & 8,5 & $+/-20 \%$ \\
\hline
\end{tabular}

3 підземними водами від звалищ відходів у грунти потрапляє велика кількість забруднювальних речовин, які потім надходять до підземних (особливо грунтових) вод і у відкриті водойми, що призводить до забруднення джерел водопостачання населення. Крім того, внаслідок розчеплення органічних речовин відходів, особливо тих, що легко загнивають, утворюються гази 3 неприємним запахом $\left(\mathrm{NH}_{3}, \mathrm{H}_{2} \mathrm{~S}, \mathrm{C}_{8} \mathrm{H}_{7} \mathrm{~N}\right.$, меркаптани), які забруднюють атмосферне повітря. Ці негативні прояви впливають на утворення гідрохімічної небезпеки, а також небезпеки забруднення атмосферного повітря.

Атмосферне повітря забруднюється під час гниття та горіння побутових відходів, а також випаровування з поверхні сміттєзвалища. Під час спалювання побутових відходів 3 продуктами згорання в атмосферу надходять: пил 150-250 мг $/ \mathrm{M}^{3}$; $\mathrm{SO}_{2}-50-200 \mathrm{M \Gamma} / \mathrm{M}^{3} ; \mathrm{HCL}-200-1000 \mathrm{мг} / \mathrm{M}^{3} ; \mathrm{CO}-$ до $0,3 \%$; альдегіди та органічні кислоти $-0,3-$ 


\section{СТОРІНКА МОЛОДОГО ВЧЕНОГО}

1,5 \%; канцерогенні речовини - 6,5-7 мг/т сміття; наявні сліди HF і діоксинів [4].

Навіть у разі спалювання твердих побутових відходів на спеціальних заводах, які є у великих містах, в атмосферу надходять продукти згорання. Шлак накопичується, і його поверхня є потужним джерелом пилу.

Одним із основних факторів впливу полігонів твердих побутових відходів на атмосферу є звалищний газ - газ, що утворюється в результаті анаеробного бродіння відходів у тілі полігону. Основними компонентами звалищного газу $\epsilon$ парникові гази: двооксид вуглецю та метан. Крім того, сміттєзвалища містять багато токсичних органічних сполук, які є джерелами забруднення атмосфери та неприємного запаху. Виділення ЗГ залежить від багатьох параметрів: вологості, кислотності, щільності, хімічного та морфологічного складу, а також від терміну зберігання ТПВ. Морфологічний склад ТПВ є визначальним для складу ЗГ та для інтенсивності його виділення [2]. Він суттєво залежить від рівня розвитку країни, пори року, географічного розміщення.

Відомо, що максимальні об'єми утворення ЗГ спостерігаються протягом перших років генерації, коли основний внесок мають матеріали, що легко розкладаються (харчові продукти, папір, деревина) [1]. На долю довгострокових емісій, за рахунок матеріалів, що важко розкладаються, припадає не більше $20 \%$ від загального об'єму емісії. Проте враховуючи тенденції збільшення вмісту в ТПВ таких матеріалів, сьогодні спостерігається збільшення об'ємів довгострокових емісій, а відповідно виникає задача моніторингу законсервованих полігонів, які є джерелами емісії ЗГ протягом десятків і сотень років після закриття полігону. Крім основних компонентів до складу ЗГ полігонів ТПВ входять такі мікрокомпоненти: толуол, аміак, ксилол, оксид вуглецю, двооксид азоту, формальдегід, етилбензол, ангідрид сірчистий та сірководень. Сумарний їх об'єм не перевищує 3 \% від загального об'єму біогазу. Проте гранично допустимі концентрації цих газів суттєво менші ніж допустимий рівень метану (в 100-1000 разів). Тому слід очікувати, що вони можуть чинити токсичний вплив на живі організми, зокрема й на людину.

Для визначення виходу біогазу за період його активної генерації можна використовувати рівняння [3]:

$\mathrm{QW}=10-6 \times \mathrm{R} \times(100-\mathrm{W}) \times(0,92 \times Ж+0,62 \times \mathrm{y}+$ $+0,34 \times$ Б),

де Qw - питомий вихід біогазу за період його активної генерації, кг/кг відходів;

R - вміст органічної складової у відходах, \%;
Ж - вміст жироподібних речовин в органічній складовій відходів, \%;

У - вміст вуглеводних речовин в органічній складовій відходів, \%;

Б - вміст білкових речовин в органічній складовій відходів, \%.

Висновок і перспективи подальших розвідок у даному напрямі. Проаналізувавши, можна зробити висновки про необхідність жорсткого контролю за станом несанкціонованих та організованих сміттєзвалищ. Результати проведених досліджень стану грунтів та атмосферного повітря у зоні впливу несанкціонованих звалищ відходів показали, що вміст шкідливих речовин як у грунті, так і у атмосферному повітрі значно перевищує ГДК.

Основні пріоритети у сфері поводження з відходами:

- впровадження стандартів СС до нормативноправової бази України у сфері поводження з відходами;

- мінімізація відходів за рахунок розроблення та впровадження технологій більш чистого виробництва, покращання екологічних характеристик продукції, зменшення обсягів пакувальних матеріалів на одиницю продукції;

- зниження техногенного впливу відходів на довкілля, особливо в районах концентрації промислового виробництва;

- розвиток вторинного ресурсокористування 3 відповідною інфраструктурою, що забезпечить сталу роботу переробних підприємств.

- удосконалення нормативно-технічного (стандарти), методичного, організаційного та інформаційного забезпечення сфери поводження з відходами.

Можна зробити висновок, що внаслідок росту виробництва, споживчої активності населення, нераціонального використання ресурсів, обмеженого залучення вторинних ресурсів у виробництво, відсутність дієвих організаційноекологічних механізмів стимулювання рециркуляції відходів, проблема твердих побутових відходів набула глобального характеру. Існує необхідність створення систем управління відходами на місцевому та регіональному рівнях 3 резервуванням земельних ділянок для об'єктів поводження 3 відходами за оптимізованими екологічнобезпечними технологіями. Також необхідно вдосконалювати як диференційоване вивезення ТПВ, так і їхню переробку [5].

Тверді побутові відходи несуть значну санітарну небезпеку, тому що є сприятливим середовищем для розвитку паразитичної фауни, патогенної мікрофлори (черевний тиф, дезентерія, 


\section{СТОРІНКА МОЛОДОГО ВЧЕНОГО}

туберкульоз та ін.), служать місцем розмноження переносників інфекційних захворювань - гризунів та мух.

У разі підвищеного вітру летючі компоненти сміття забруднюють значну площу поблизу полігону.

За результатами проведених досліджень бачимо, що під впливом полігонів твердих побутових відходів, на прикладі полтавського звалища відбувається зараження підземних та поверхневих вод. Так, хімічний аналіз води із криниці найближчого населеного пункту до полтавського міського звалища - села Макухівка - виявив наявність значної кількості металів (марганця, свинцю, алюмінію, кадмію). Забруднені фільтратом грунтові води, що течуть до річки Коломак, $є$ серйозним, постійно діючим, багатокомпонентним джерелом забруднення, вплив якого необхідно ліквідувати або мінімізувати. Під впливом

\section{БІБЛІОГРАФІЯ}

1. Армишева Г.T. Снижение экологической загрузки при обращении с твердыми бытовыми отходами за счет использования горючих компонентов / Г. Т. Армишева, В.Н.Коротаев, В. Г. Кривошеин // Научные исследования и инновации : научный журнал. - 2010. - Т. 4, №3. С. 3-8.

2. Гелетуха Г.Г., Маризенюк 3. А. Обзор технологий добычи и использования биогаза на свалках и полигонах твердых бытовых отходов и перспективы их развития в Украине / Г. Г. Гелетуха, 3. А. Марценюк // Экотехнологии и ресурсосбережение. - 1999. - №4. - С. 6-14.

3. Методика расчета количественных характеристик выбросов загрязняющих веществ в атмосферу от полигонов твердых бытовых и промышленных отходов / [Абрамов Н. Ф., Санников Э. С., Русаков К. Б. и др.]. - М. : АКХ им. К. Д. Памфилова, 2004. - 28 с. - (Нормативный документ).

4. Научу H. B. Екологічна безпека атмосферного повітря територій навколо полігонів твер- полігонів твердих побутових відходів відбувається забруднення грунту продуктами вилуговування, виділення неприємного запаху, розкид відходів вітром, мимовільне спалахування полігонів, безконтрольне утворення метану та неестетичний вигляд є лише часткою проблеми, яка турбує екологів та викликає серйозну незгоду 3 боку місцевих мешканців. Однак у зв'язку 3 великою кількістю причин (серед яких основними $\epsilon$ нестача вільних земельних ділянок під нові полігони, відсутність коштів на їх будівництво, або впровадження прогресивних технологій поводження 3 відходами) звалища ТПВ продовжують експлуатуватися. Тому необхідним стає впровадження на полігонах ТПВ природоохоронних заходів, які дадуть змогу знизити їх навантаження на довкілля. Одним із найбільш актуальних та дієвих заходів є установка на полігонах систем збору та утилізації звалищного газу.

дих побутових відходів / Н. В. Научу, А. О. Водяник // Вісник КрНУ імені Михайла Остроградського. - 2012. - Вип. 2 (73). - С. 160-163.

5. Онищенко С. В., Самойлік М. С. Екологоекономічна оцінка забруднення навколишнього середовища в системі екологічно безпечного розвитку регіонів України / С. В. Онищенко, М. С. Самойлік. - Полтава : ПНТУ ім. Ю. Кондратюка, 2012. - 269 с.

6. Орлова T. О. Оцінки екологічного стану земельних ділянок, зайнятих відходами та об'єктами поводження 3 ними : автореф. дис. к.т.н. - К., 2008. - 148 с.

7. Протокол випробувань №2375 за договором від 06.11.2015 між Молчановою А. В. та ДП «Полтавастандартметрологія».

8. Радовенчик В. М., Гомеля М. Д. Тверді відходи: збір, переробка, складування : навч. посіб. [для студ. вищ. навч. закл.] / В. М. Радовенчик, М. Д. Гомеля. - К. : Кондор, 2010. - 550 с. 